\title{
Pengaruh Pemberian Cookies Bunite terhadap Kadar Gula Darah Sewaktu pada Penderita DM Tipe 2
}

\section{The Effect of Cookies Bunite on The Blood Glucose Level on Diabetes Mellitus Patient Type 2}

\author{
Muzakar $^{1}$, Dewi A.R ${ }^{2}$ Listrianah $^{3}$ \\ ${ }^{1,2}$ Jurusan Gizi, Politeknik Kesehatan Kementerian Kesehatan Palembang, Indonesia \\ ${ }^{3}$ Jurusan Kesehatan Gigi, Politeknik Kesehatan Kementerian Kesehatan Palembang, Indonesia
}

\section{ARTICLE INFO}

\section{Article history}

Received date

14 Sep 2021

Revised date

28 Sep 2021

Accepted date

09 Nov 2021

Keywords:

Blood glucose;

Cookies bunite;

Diabetes mellitus.

\section{Kata kunci:}

Glukosa darah;

Cookies bunite;

Diabetes Mellitus.

\author{
ABSTRACT/ ABSTRAK
}

The prevalence of DM in Indonesia in 2018 was $2.0 \%$ and in South Sumatra was 20,7\%. Non-pharmacological management of DM is by giving "cookies bunite". Research objectives are to find out the effect of giving "cookies bunite" to blood sugar levels in patients with type 2 diabetes. The type of research used was quasi-experimental with the research design "The type of research is a quasi-experiment with a pretest and posttest control group design". This research was conducted from September to March 2021 at the Public Health Center Social in Palembang. Samples were patients with type 2 Diabetes Mellitus who were selected by purposive sampling with inclusion criteria: blood sugar levels $200 \mathrm{mg} / \mathrm{dl}$ and age 40 years, male and female. The number of samples in the treatment and comparison groups was 30 respondents each. Data were collected by purposive sampling technique and selected according to the criteria. Data analysis used paired sample test and independent $\mathrm{t}$-test with the difference in the average blood glucose levels of the treatment group 45, $27 \mathrm{mg} / \mathrm{dl}(\mathrm{p}$-value $=0,00)$ and the experimental group. comparison $18,9 \mathrm{mg} / \mathrm{dl}$ ( $\mathrm{p}$-value=0,00). The difference in decreasing blood glucose levels between the intervention group was $\mathrm{mg} / \mathrm{dl}$ and the comparison group was $26.37 \mathrm{mg} / \mathrm{dl}$. The result of the independent sample test statistic is p-value $=0,013$. There was an effect of giving "cookies bunite" on blood glucose levels in patients with type 2 Diabetes Mellitus with the average difference in the treatment group being greater than in the control group. There is an effect of giving "cookies bunite" to decrease blood glucose levels in patients with type 2 Diabetes Mellitus.

Prevalensi kejadian DM di Indonesia tahun 2018 sebesar 2,0\% dan di Sumatera Selatan 20,7\%. Penatalaksanaan non farmakologi penyakit DM adalah dengan pemberian "cookies bunite". Tujuan penelitian diketahuinya pengaruh pemberian "cookies bunite" terhadap kadar gula darah sewaktu pada pasien DM tipe 2. Jenis penelitian yang digunakan quasi experiment dengan rancangan penelitian "The type of research is a quasi experiment with a pretest and posttest control group design". Penelitian ini dilakukan pada bulan September sampai Maret 2021 di Puskesmas Sosial Palembang. Sampel adalah penderita Diabetes Melllitus type 2 yang dipilih secara purposive sampling dengan kriteria inklusi: kadar gula darah $\geq 200 \mathrm{mg} / \mathrm{dl}$ dan usia $\geq 40$ tahun, laki-laki dan perempuan. jumlah sampel kelompok perlakuan dan kontrol masing-masing 30 responden. Data dikumpulkan dengan teknik purpossive sampling dan dipilih sesuai kriteria. Analisis data menggunakan paired sample test dan independent t-test dengan selisih rata-rata kadar glukosa darah kelompok perlakuan $45,27 \mathrm{mg} / \mathrm{dl}(p$-value $=0,00)$ dan kelompok kontrol $18,9 \mathrm{mg} / \mathrm{dl}$ ( $p$-value $=0,00)$. Perbedaan penurunan kadar glukosa darah antara kelompok intervensi $\mathrm{mg} / \mathrm{dl}$ dan pada kelompok kontrol $26,37 \mathrm{mg} / \mathrm{dl}$. Hasil uji statistik independent sample test adalah $p$-value $=0,013$. Hasil menunjukkan bahwa ada pengaruh pemberian "cookies bunite" terhadap kadar glukosa darah sewaktu pada penderita Diabetes Mellitus tipe 2 dengan selisih rat-rata kelompok perlakuan lebih besar dibandingkan pada kelompok kontrol. Ada pengaruh pemberian "cookies bunite" terhadap penurunan kadar glukosa darah penderita Diabetes Mellitus type 2 .

Corresponding Author:

Muzakar

Jurusan Gizi, Politeknik Kesehatan Kementerian Kesehatan Palembang, Indonesia

Email: zackmuba@yahoo.co.id 


\section{PENDAHULUAN}

Saat ini dunia telah mengalami pergeseran tren dari Penyakit Menular (PM) ke Penyakit Tidak Menular (PTM) atau biasa dikenal dengan penyakit degeneratif. Faktor yang menjadi penyebab terjadinya PTM diantaranya adalah pola makan yang salah, obesitas, hipertensi, hiperkolestrolimia, kebiasaan merokok, aktifitas fisik, stress, hiperglikemi untuk menindaklanjuti hal ini maka dilakukan konseling kesehatan dan merujuk ke pelayanan kesehatan segera (Kementerian Kesehatan RI, 2014).

Organisasi Internasional Diabetes

Federation (IDF) telah memperkirakan prevalensi diabetes mellitus (tipe 1 dan gabungan tipe 2, baik yang terdiagnosis maupun yang tidak terdiagnosis) pada orang berusia 20-79 tahun telah meningkat dari 151 juta (4,6\% dari populasi global pada saat itu) menjadi 463 juta $(9,3 \%)$ hari ini. Diperkirakan meningkat menjadi 578 juta orang $(10,2 \%)$ pada tahun 2030 dan Jumlah itu akan melonjak menjadi 700 juta $(10,9 \%)$ pada tahun 2045 ( IDF, 2019).

Hasil survey dari Riskesdas Tahun 2018 menyebutkan bahwa angka kejadian diabetes mellitus di Indonesia pada kelompok umur $>15$ tahun mengalami peningkatan dari $1,5 \%$ pada tahun 2013 menjadi $2,0 \%$ pada tahun 2018 dan diperkirakan pada tahun 2030 mencapai 21,3 juta jiwa. Data laporan riskesdas Sumatera Selatan tahun 2018, prevalensi $0,9 \%$, sedangkan kota Palembang menempati urutan pertama dari 17 kabupaten/kota yaitu $1,6 \%$ (Kementerian Kesehatan, 2018).

Berdasarkan Data Profil Kesehatan Kota Palembang Tahun 2018, diabetes mellitus tertinggi berada di Kota Palembang sebesar $20,7 \%$. Berdasarkan data yang telah didapatkan prevalensi penyakit diabetes mellitus di Puskesmas Sosial Palembang mengalami kenaikan yaitu pada tahun 2018 sebesar 38,6\% sedangkan 2019 sebesar 39\% (Dinas Kesehatan Kota Palembang 2019).

Tepung labu kuning merupakan tepung dengan butiran halus yang berasal dari labu kuning, bewarna kuning dan memiliki bau khas labu kuning, tepung labu kuning mengandung serat pangan yang tinggi. Penelitian yang dilakukan oleh Farvid, et al. (2014) menunjukkan bahwa mengkonsumsi pangan tinggi serat, amilosa dan indeks glikemik rendah mampu memperbaiki sensitivitas insulin, menurunkan laju penyerapan glukosa serta bermanfaat dalam pengendalian glukosa darah sehingga dapat menurunkan resiko komplikasi pada penderita diabetes mellitus tipe 2 .
Penelitian yang pernah dilakukan oleh Fathonah, et al. (2014) menyebutkan tepung labu kuning mengandung flavonoid yang berfungsi dalam menghambat enzim a-amylase maltase dan a-glukosidase. Prinsip dari penghambatan pada enzim tersebut yaitu akan menyebabkan penundaan hidrolisis karbohidrat dan disakarida, menghambat absorbs glukosa dan menghambat metabolism sukrosa menjadi glukosa serta fruktosa sehingga kadar gula darah dapat turun. Penelitian yang dilakukan oleh Wahyuning (2017) menunjukkan pemberian tepung labu kuning $0,64 \mathrm{~g}$ pada tikus mengalami penurunan rerata kadar glukosa darah dari $137,6 \mathrm{~g} / \mathrm{dl}$ menjadi $86,02 \mathrm{~g} / \mathrm{dl}$.

Tepung tempe merupakan salah satu produk hasil pengolahan dari tempe. Kandungan isoflavon berupa genistein dapat menghambat $\alpha$ glukosidase yang berperan pada beberapa kelainan metabolik seperti Diabetes Mellitus (DM) (Ghozali DS, et al., 2010 dalam Rahadiyanti dan Mulyati, 2017). Menurut penelitian yang telah dilakukan oleh Li et al. (2010) menunjukkan bahwa pada 15 wanita menopause yang sehat setelah diberikan $15 \mathrm{~g}$ protein kedelai dan $100 \mathrm{mg}$ isoflavon terdapat penurunan kadar glukosa darah 2 jam postpradinal sebesar 2,34\%.

Berdasarkan berbagai penelitian menggunakan tepung pengganti bagi penderita DM tersebut, sehingga peneliti tertarik untuk mengetahui pengaruh pemberian"cookies bunite" terhadap kadar gula darah sewaktu pada pasien DM tipe 2.

\section{METODE}

Jenis penelitian ini termasuk penelitian analitik dengan rancangan penelitian quasi eksperimen, melakukan percobaan terhadap kelompok perlakuan yang diberi "cookies bunite" dan menggunakan kelompok kontrol.

Penelitian ini dilakukan di Puskesmas Sosial pada bulan September 2020-Maret 2021. Populasi pada penelitian ini yaitu penderita diabetes tipe 2 yang berada di wilayah kerja Puskesmas Sosial.

Besar sampel yang digunakan 60 responden terdiri dari 30 kelompok perlakuan dan 30 kelompok kontrol menggunakan rumus Lameshow. Penelitian ini telah melewati kaji etik dan memperoleh Ethical Approval dari Komite Etik Penelitian Kesehatan Politeknik Kesehatan Kemenkes Palembang dengan Nomor. 663 KEPK/Adm2/I/2021. 


\section{HASIL}

Tabel 1. Hasil Uji Organoleptik

\begin{tabular}{crrr}
\hline Penilaian & \multicolumn{1}{c}{ F1 } & \multicolumn{1}{c}{ F2 } & \multicolumn{1}{c}{ F3 } \\
& Rata-rata & Rata-rata & Rata-rata \\
\hline Aroma & 3,10 & 3,63 & 4,10 \\
Tekstur & 2,93 & 3,80 & 3,30 \\
Warna & 3,30 & 3,80 & 3,43 \\
Rasa & 3,10 & 3,93 & 3,37 \\
\hline
\end{tabular}

Tabel 2. Hasil Laboratorium Cookies Bunite

\begin{tabular}{lrr}
\hline \multicolumn{1}{c}{ Jenis Analisa } & Komposisi & \multicolumn{1}{c}{ Metode } \\
\hline Kadar Air (\%) & 17,08 & SNI 01-2891- \\
& & 1992 \\
Kadar Abu (\%) & 2,84 & SNI 01-2891- \\
& & 1992 \\
Kadar lemak (\%) & 22,32 & SNI 01-2891- \\
& 1992 \\
Kadar protein (\%) & 22,53 & SNI 01-2891- \\
& & 1992 \\
Kadar & 35,22 & By difference \\
Karbohidrat (\%) & & $18-8-6-$ \\
Serat Pangan & 20,14 & 2/MU/SMM- \\
& & SIG \\
\hline
\end{tabular}

Uji Organoleptik dilakukan di Poltekkes Kemenkes Palembang Jurusan Gizi yang terdiri dari 30 orang panelis yaitu mahasiswa semester 5-7. Uji organoleptik dilakukan terhadap ketiga formula "cookies bunite" F1, F2, dan F3. Hasil uji organoleptik disajikan dalam tabel 1 , nilai gizi "cookies bunite" disajikan dalam tabel 2 .

Untuk melihat perbedaan organoleptik maka hasil uji organoleptik dianalisis dengan statistik Friedman test, yang hasil dapat dilihat pada grafik dibawah ini, dimana F2 mempunyai tingkatan tertinggi kecuali pada F1.

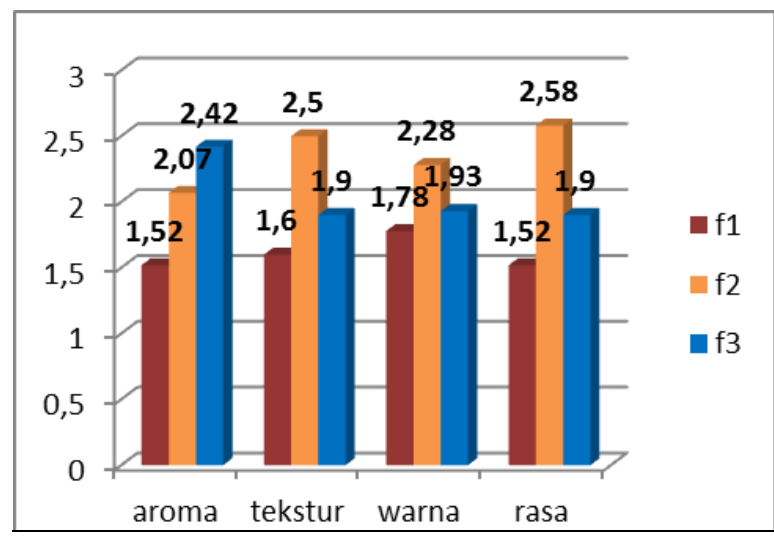

Grafik 1. Hasil Uji Friedman

Tabel 3. Karakteristik Responden

\begin{tabular}{lrrrr}
\hline Karakteristik & \multicolumn{2}{c}{ Perlakuan } & \multicolumn{2}{c}{ Kontrol } \\
\cline { 2 - 5 } Responden & n & \% & \multicolumn{1}{c}{ n } & \% \\
\hline Usia & & & & \\
$41-50$ & 5 & 16,7 & 4 & 13,3 \\
$51-60$ & 8 & 26,7 & 8 & 26,7 \\
$\quad 61-70$ & 17 & 56,6 & 18 & 60 \\
Jenis Kelamin & & & & \\
$\quad$ Laki-laki & 12 & 40 & 12 & 40 \\
$\quad \begin{array}{l}\text { Perempuan } \\
\text { Riwayat Keluarga }\end{array}$ & 18 & 60 & 18 & 60 \\
$\quad$ Ada & 14 & 46,7 & 15 & 50 \\
$\quad$ Tidak Ada & 16 & 53 & 15 & 50 \\
\hline
\end{tabular}

Tabel 4. Uji Homogenitas Rata-rata Kadar Glukosa Darah Sebelum dan Sesudah Intervensi

\begin{tabular}{lcrrrrr}
\hline \multirow{2}{*}{ Sebelum } & Kelompok & Jumlah & GDS tertinggi & GDS terendah & Rata-rata & p-value \\
\multirow{3}{*}{ Sesudah } & Perlakuan & 30 & 343 & 202 & 249,37 & \multirow{2}{*}{0,321} \\
& Kontrol & 30 & 312 & 201 & 246,13 & \multirow{2}{*}{ Perlakuan } \\
\cline { 2 - 6 } & Kontrol & 30 & 354 & 150 & 204,10 & \multirow{2}{*}{0,186} \\
\hline
\end{tabular}

Tabel 5. Perbedaan Glukosa Darah Sebelum dan Setelah Perlakuan

\begin{tabular}{ccrrrr}
\hline $\boldsymbol{t}$-test & Kelompok & Mean awal \pm SD & Mean akhir \pm SD & $p$-value & \multicolumn{1}{c}{ t } \\
\hline \multirow{2}{*}{ Uji t-dependent } & Perlakuan & $249,37 \pm 37,506$ & $204,10 \pm 43,443$ & 0,00 & 12,006 \\
Uji t-independent & Kontrol & $246,13 \pm 31,108$ & $229,33 \pm 31,719$ & 0,00 & 5,566 \\
& Perlakuan & 60 & $-25,233 \pm 9,821$ & 0,01 & $-2,569$ \\
\hline
\end{tabular}

Karakteristik responden terdiri dari usia, jenis kelamin, riwayat keluarga disajikan dalam tabel 3, analisis univariat disajikan dalam tabel 4, rata-rata kadar glukosa darah sebelum intervensi pada kelompok perlakuan dan kelompok kontrol disajikan dalam tabel 5, rata-rata kadar glukosa darah setelah intervensi pada kelompok perlakuan dan kelompok kontrol disajikan dalam tabel 6, perbedaan kadar glukosa darah sebelum dan setelah perlakuan disajikan dalam tabel 7 . Kelompok perlakuan adalah kelompok responden yang diberikan cookies bunite dan obat diabetes sedangkan kelompok kontrol diberikan leaflet dan obat diabetes. 


\section{PEMBAHASAN}

\section{Hasil Uji Organoleptik}

Dari hasil uji terhadap aroma diketahui bahwa nilai skor rangking rata-rata penerimaan panelis berkisar antara 3,10-4,10. Berdasarkan hasil yang didapat Formula F2 menempat 3 peringkat tertinggi dari 4 kriteria yang diujikan.

Dari hasil uji yang dilakukan dapat diketahui bahwa semakin tinggi proporsi tepung labu kuning di dalam produk cookies dapat menurunkan kesukaan panelis karena aroma langu pada cookies. Hal ini sesuai dengan penelitian Rasyid, et al. (2020) bahwa cookies dengan penambahan tepung labu kuning memiliki aroma yang langu karena adanya flavonoid pada tepung labu kuning.

Hasil uji terhadap tekstur didapatkan hasil rata-rata 2,93-3,80. Tekstur cookies ini cenderung lebih keras, penambahan tepung tempe yang merupakan salah satu patah menyebabkan nilai kekerasan cookies meningkat.

Untuk warna dihasilkan nilai rata-rata antara 3,30-3,80. Hasil ini menunjukkan proporsi tepung labu kuning lebih banyak dapat menyebabkan warna cookies lebih gelap. Hal ini didukung oleh Rachmawati, et al. (2016) bahwa proporsi labu kuning yang banyak dapat menyebabkan warna biscuit menjadi lebih gelap yang disebabkan oleh pigmen karetonoid yang terdapat pada tepung labu kuning.

Rasa merupakan faktor penentu daya terima konsumen. Dari hasil uji organoleptik yang dilakukan didapatkan hasil rata-rata berkisar 3,10-3,93. Hasil ini menunjukkan bahwa semakin tinggi konsenterasi tepung labu kuning dapat menyebabkan panelis tidak menyukai cookies karena memiliki rasa langu. Hal ini didukung oleh Rasyid, et al. (2020) bahwa semakin banyak penambahan tepung labu kuning maka nilai kesukaan panelis semakin menurun.

Proporsi penambahan tepung labu kuning berpengaruh terhadap kadar air karena pada tepung labu kuning kadar air masih tinggi. Hal ini sejalan dengan penelitian Ratnasari dan Yunianta (2015) kadar air biskuit semakin tinggi seiring semakin banyak proporsi tepung labu kuning yang ditambahkan. Tepung labu kuning hasil penelitian memiliki butiran halus namun kadar airnya masih terlalu tinggi dan memengaruhi kadar abu.

Serat pangan pada uji yang dilakukan didapatkan hasil 20,14 . Serat pangan yang tinggi memiliki manfaat bagi penderita DM tipe 2 .

\section{Karakteristik Responden berdasarkan Usia}

Karakteristik responden dalam penelitian ini sebagian besar berusia 61-70 tahun. Penelitian yang dilakukan Desy (2016 dalam Nugroho dan Wijayanti, 2018) hasil menunjukkan bahwa sebagian besar penderita diabetes mellitus berusia di atas 60 tahun dan terdapat banyak responden penderita Diabetes Mellitus pada rentang usia 50-59 tahun. Selain itu penelitian ini didukung oleh penelitian Wicaksono (2011) bahwa usia 45 tahun tubuh mengalami penurunan fungsi dalam metabolisme glukosa darah.

Usia $\geq 45$ tahun memiliki resiko terkena penyakit diabetes mellitus lebih tinggi karena terjadi resistensi insulin yang disebabkan oleh perubahan komposisi tubuh, penurunan fungsi tubuh dalam metabolisme glukosa, menurunnya aktifitas fisik yang menjadi salah satu faktor dalam penurunan jumlah reseptor insulin sehingga insulin yang dihasilkan lebih sedikit ataupun tidak bekerja sebagaimana mestinya.

\section{Karakteristik Responden Berdasarkan Jenis Kelamin}

Dari hasil penelitian yang telah dilakukan dapat diketahui bahwa dari 60 sampel pada setiap kelompok penderita Diabetes Mellitus yaitu pada kelompok perlakuan maupun kontrol sebagian besar berjenis kelamin perempuan yaitu 18 orang $(60 \%)$.

Penelitian yang dilakukan oleh Wen Chen dan Tseng (2012) menemukan bahwa persentase nilai $\mathrm{HbAIc} \geq 6,5$ pada perempuan $66,7 \%$. Hal ini didukung oleh penelitian dari Dedy (2010 dalam Ramadhan, 2015) bahwa angka kejadian terkena Diabetes Mellitus jenis kelamin perempuan dan laki-laki memiliki resiko sama, akan tetapi faktor resiko perempuan memiliki peluang lebih besar diakibatkan IMT yang lebih besar, sindrom siklus bulanan (premenstrual syndrome), pasca-menopause yang mengakibatkan distribusi lemak menjadi lebih mudah terakumulasi akibat proses hormonal sehingga perempuan lebih beresiko menderita Diabetes Mellitus.

\section{Serat}

Asupan serat pada pasien diabetes mellitus sangat penting, Penelitian yang dilakukan oleh Farvid, et al. (2014) mengatakan bahwa mengkonsumsi pangan tinggi serat, amilosa dan indeks glikemik rendah mampu memperbaiki sensitivitas insulin, menurunkan laju penyerapan glukosa serta bermanfaat dalam pengendalian 
glukosa darah sehingga dapat menurunkan resiko komplikasi pada penderita Diabetes Mellitus tipe 2.

Hasil ini sejalan dengan penelitian (Immawati dan Wirawanni, 2014) subjek yang mengkonsumsi diit tinggi serat menunjukkan penurunan kadar insulin dan glukosa darah sebesar $12 \%$ dan $10 \%$. Hal tersebut dikarenakan serat pangan mampu menyerap air dan mengikat glukosa, sehingga mengurangi ketersediaan glukosa.

\section{Pengaruh Pemberian Cookies Bunite terhadap Penurunan Kadar Glukosa Darah}

Hasil uji statistik ( $t$-dependent) didapatkan baik pada kelompok perlakuan maupun kelompok kontrol nilai $p$-value $=0,000$, memiliki nilai yang sama signifikan, sehingga perlu dilajutkan dengan analisis statistik t-independent, apakah penurunan kadar glukosa darah dipengaruhi pemberian cookies bunite.

Hasil uji statistik ( $t$-independent), rata-rata selisih kadar glukosa darah terhadap $p$ value $=0,013$ pada $\alpha<0,05$ sehingga dapat disimpulkan bahwa ada pengaruh pemberian cookies bunite terhadap kadar glukosa darah pada penderita Diabetes Mellitus Tipe 2. Hal ini dikarenakan tepung labu kuning dan tepung tempe pada cookies bunite terdapat kandungan seperti antioksidan, flavonoid, dan serat yang dapat membantu mengatur dan menurunkan kadar glukosa didalam darah.

Kandungan flavonoid pada buah labu kuning dapat menghambat enzim a-amylase maltase dan a-glukosidase. Prinsip dari penghambatan pada enzim tersebut yaitu akan menyebabkan penundaan hidrolisis karbohidrat dan disakarida, menghambat absorbs glukosa dan menghambat metabolism sukrosa menjadi glukosa serta fruktosa sehingga kadar gula darah dapat turun Fathonah, et al. (2014). Kebutuhan asupan flavonoid sehari sebesar $50-59 \mathrm{mg} /$ hari diperlukan setiap manusia guna menjaga kesehatan tubuh (Masruhen, 2010; Holick et al., 2002 dalam Maulida dan Adi, 2018). Penelitian yang pernah dilakukan oleh Valenzuela, et al., (2014) menunjukkan bahwa kandungan flavonoid pada labu kuning menggunakan methanol yaitu $0,53 \mathrm{mg} / \mathrm{g}$ sampel, maka diperkirakan kandungan flavonoid yang terdapat pada cookies bunite yaitu $53 \mathrm{mg}$ per 100gr, dalam sehari responden diberikan 40gr sehingga cookies diperkirakan menyumbangkan $21,2 \mathrm{mg}$ flavonoid dan $35 \%$ dari asupan harian responden yang berfungsi sebagai antioksidan sehingga membantu penurunan kadar glukosa darah.
Isoflavon yang terdapat pada cookies bunite diperkirakan sebanyak $54,18 \mathrm{mg}$ per $100 \mathrm{gr}$ hal ini berdasarkan penelitian Hall (2014) bahwa kandungan isoflavon tempe yaitu $0,5418 \mathrm{mg} / \mathrm{g}$ sampel. Dalam sehari responden diberikan $40 \mathrm{gr}$ sehingga cookies diperkirakan menyumbangkan $21,6 \mathrm{mg}$.

Penelitian lain menunjukkan hasil yang berbeda dimana pemberian $15 \mathrm{gr}$ protein kedelai dan $100 \mathrm{mg}$ isoflavon pada wanita post menopause prediabetes didapatkan hasil tidak memperbaiki sensitifitas insulin dan kontrol gula darah (Liu ZM, et al., 2010)

Penelitian yang dilakukan oleh Immawati dan Wirawanni (2014) menunjukkan subjek yang mengkonsumsi serat tinggi menunjukkan penurunan kadar insulin dan glukosa darah sebesar $12 \%$ dan $10 \%$.

Hal ini didukung oleh penelitian S.Gropper dan Smith (2013) bahwa serat merupakan komponen yang tidak dapat dicerna dan diserap di dalam usus halus. Bagian serat yang tidak tercerna akan menuju ke dalam usus besar. Serat akan diubah menjadi substrat yang dapat difermentasikan oleh bakteri di alam usus besar. Fermentasi serat oleh bakteri menghasilkan asam-asam lemak rantai pendek jenis asetat, propionat dan butirat. Asam-asam lemak tersebut akan diserap kembali menuju ke aliran darah. Asetat kemungkinan dapat menurunkan asamasam lemak bebas di aliran darah dalam jangka waktu yang lama. Hal ini mempunyai efek baik bagi penurunan kadar glukosa darah dan sensitivitas insulin dalam jangka waktu lama karena asam-asam lemak bebas dapat menghambat proses utilasi glukosa di jaringan dan memperburuk resistensi insulin.

Serat pada cookies bunite yaitu 20,14gr per $100 \mathrm{gr}$ cookies, dalam sehari responden diberikan 40gr cookies sehingga cookies menyumbangkan $8 \mathrm{gr}$ dan $32 \%$ kebutuhan harian asupan serat. Serat dapat menyerap cairan dan membentuk gel di dalam lambung. Hal ini didukung oleh penelitian J.Luo, et.al (dalam Immawati dan Wirawanni, 2014) serat dapat menyerap cairan dan membentuk gel, gel memperlambat proses pengosongan lambung dan penyerapan zat gizi. Gel dapat memperlambat gerak peristaltik zat gizi (glukosa) dari dinding usus halus menuju daerah penyerapan sehingga terjadi penurunan kadar glukosa darah.

Cookies bunite ini dapat dijadikan selingan yang sehat untuk penderita Diabetes Mellitus. Selain itu juga bahan dasar dari cookies bunite bahan yang mudah untuk didapat dan juga dengan harga yang murah. 


\section{SIMPULAN}

Berdasarkan
pembahasan yang telah diuraikan dapat

\section{DAFTAR PUSTAKA}

Dinas Kesehatan Kota Palembang. (2019). Profil Kesehatan Kota Palembang. Palembang.

Farvid, M. S., Homayouni, F., Shokoohi, M., Fallah, A., \& Farvid, M. S. (2014). Glycemic index, glycemic load and their association with glycemic control among patients with type 2 diabetes. European Journal of Clinical Nutrition, 68(4), 459463. https://doi.org/10.1038/ejen.2013.288

Fathonah, R., Indriyanti, A., \& Kharisma, Y. (2014). Labu Kuning ( Cucurbita moschata Durch.) untuk Penurunan Kadar Glukosa Darah Puasa pada Tikus Model Diabetik. In Global Medical \& Health Communication. https://doi.org/10.29313/GMHC.V2I1.1527

Hall, J. (2014). Guyton dan Hall Buku Ajar Fisiologi Kedokteran (M. Widjajakusuma, A. Tanzil, \& E. Ilyas (eds.); 12th ed.). Elsevier (Singapore). https://www.elsevier.com/books/guytondan-hall-buku-ajar-fisiologikedokteran/hall/978-981-4371-18-6

IDF. (2019). IDF Diabetes Atlas, the Seventh Edition.

http://www.diabetesatlas.org/resources/201 7-atlas.html

Kementerian Kesehatan RI. (2014). Pedoman Umum Pos Pembinaan Terpadu Penyakit Tidak-Menular. Direktorat Jenderal Pengendalian Penyakit dan Lingkungan. http://p2ptm.kemkes.go.id/uploads/2016/1 0/Pedoman-Umum-Pos-PembinaanTerpadu-Penyakit-Tidak-Menular.pdf

Kementerian Kesehatan RI. (2018). Laporan Riskesdas 2018. Jakarta: Balitbangkes.

Li, S. H., Liu, X. X., Bai, Y. Y., Wang, X. J., Sun, K., Chen, J. Z., \& Hui, R. T. (2010). Effect of oral isoflavone supplementation on vascular endothelial function in postmenopausal women: A meta-analysis of randomized placebo-controlled trials. American Journal of Clinical Nutrition, 91(2), 480-486. https://doi.org/10.3945/ajcn.2009.28203

Liu ZM, Chen Y, Suzanne CH, Ho YP, Woo J. (2010). Effects Soy Protein And Isoflavones On Glycemic Control And Insulin Sensitivity : Randomized, Placebo Control Trial In Postmenopause Chinese disimpulkan bahwa "Cookies Bunite" dapat menurunkan kadar glukosa darah penderita Diabetes Mellitus Tipe 2 secara bermakna.

Women. The American Journals of Clinical Nutrition. 91(5), 1394-1401.

Maulida, V. S., \& Adi, A. C. (2018). Daya Terima Dan Kandungan Flavonoid Sirup Kombinasi Belimbing Wuluh (Averrhoa Bilimbi L) Dan Daun Tin (Ficus Carica L) Sebagai Minuman Alternatif Antioksidan Kaya Flavonoid. Media Gizi Indonesia, 13(2), 159. https://doi.org/10.20473/mgi.v13i2.159-167

Nugroho, P. S., \& Wijayanti, A. C. (2018). Indeks Masa Tubuh Dan Kaitannya Dengan Diabetes Melitus Pada Umur > 15 Tahun Di Indonesia, Studi Data Survei Kehidupan Keluarga Indonesia V. Jurnal Publikasi Kesehatan Masyarakat Indonesia, 5(1), 12. https://doi.org/10.20527/jpkmi.v5i1.4998

Immawati, F. R., \& Wirawanni, Y. (2014). Hubungan konsumsi karbohidrat, konsumsi total energi, konsumsi serat, beban glikemik dan latihan jasmani dengan kadar glukosa darah pada pasien diabetes mellitus tipe 2. Diponegoro Journal of Nutrition and Health, 2(3), 89842. https://doi.org/10.14710/jnh.2.3.2014.\%p

Rahadiyanti, A., \& Mulyati, T. (2017). Efek Tempe Kedelai Terhadap Penurunan Kadar Glukosa Darah Pada Prediabetes. Darussalam Nutrition Journal, 1(2), 1930.

Ramadhan, N., \& Marissa, N. (2015). Karakteristik penderita diabetes mellitus tipe 2 berdasarkan kadar hbalc di puskesmas jayabaru kota banda aceh. Journal of Rheumatology, 2, 49-56.

Rasyid, M. I., Maryati, S., Triandita, N., Yuliani, H., \& Angraeni, L. (2020). Karakteristik Sensori Cookies Mocaf dengan Substitusi Tepung Labu Kuning. Jurnal Teknologi Pengolahan Pertanian, 2(1), 1-7. http://jurnal.utu.ac.id/jtpp/article/view/2043

Ratnasari, D., \& Yunianta. (2015). Pengaruh Tepung Kacang Hijau, Tepung Labu Kuning, Margarin terhadap Fisikokima dan Organoleptik Biskuit. Pangan Dan Agroindustri, 3(4), 1652-1661.

S.Gropper, S., \& Smith, J. L. (2013). Advanced Nutrition and Human Metabolism 6th Edition (4th ed.). Thomson Wadsworth. 
Valenzuela, G. M., Soro, A. S., Tauguinas, A. L., Gruszycki, M. R., Cravzov, A. L., Giménez, M. C., \& Wirth, A. (2014). Evaluation Polyphenol Content and Antioxidant Activity in Extracts of Cucurbita spp. OALib, 01(03), 1-6. https://doi.org/10.4236/oalib.1100414

Wahyuni, D. (2017). Tepung Labu Kuning (Cucurbita Moschata) Menurunkan Kadar Glukosa Darah Tikus Model Sindroma Metabolik. Jurnal Aisyah: Jurnal Ilmu Kesehatan, 2(1), 11-16.
Wen Chen, K.-, \& Tseng, H.-M. (2012). The Barriers to Initiating Insulin Therapy among People with Type 2 Diabetes in Taiwan - A Qualitative Study. Journal of Diabetes \& Metabolism, 03(05), 3-6. https://doi.org/10.4172/2155-6156.1000194

Wicaksono, R. P. (2011). Faktor-Faktor Yang Berhubungan Dengan Kejadian Diabetes Melitus Tipe 2 (Studi Kasus di Poliklinik Penyakit Dalam Rumah Sakit Dr. Kariadi. [Skripsi]. Semarang: Fakultas Kedokteran, Universitas http://eprints.undip.ac.id/37123/ 